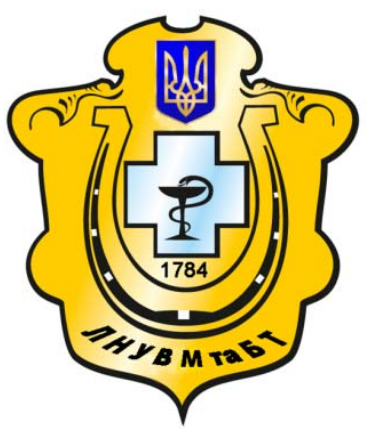

Науковий вісник Львівського національного університету ветеринарної медицини та біотехнологій імені С.3. Гжицького

Scientific Messenger of Lviv National University of Veterinary Medicine and Biotechnologies named after S.Z. Gzhytskyj

doi:10.15421/nvlvet7047

ISSN 2413-5550 print

ISSN 2518-1327 online

$\underline{\text { http://nvlvet.com.ua/ }}$

УДК 636.39.053.087.7:614.9:612.017

\title{
Неспеціфічна резистентність козенят за дії пробіотика «Евіталія» в умовах не регульованого мікроклімату
}

\author{
А.М. Петренко, Л.Л. Кущ \\ Petrenko@e-mail.ua \\ Харківська державна зооветеринарна академія, \\ смт. Мала Данилівка, Дергачівський район, Харківська область, 62341, Украӥна
}

\begin{abstract}
Мета роботи - дослідження полягали в виявленні впливу пробіотичної закваски «Евіталія» на неспециффічну резистентність козенят заанівскої породи в умовах мікроклімату згідно ВНТП (для вівчарських та козівничих підприємств. Отримані результати та їх новизна: вперше випробувана нова пробіотична закваска «Евіталія», при пероральному введенні ії козенятам в дозі 200 мл/голову - вранці та ввечері по 100 мл. Встановлено, щзо застосування «Евіталія» сприяє активізаціі окислювально-відновних процесів в організмі козенят, стимуляиії еритропоезу: підвищення конщентрації гемоглобіну на $0,56 \%(P \leq 0,05)$, кількість еритроичтів - 10,2\% $(P \leq 0,05)$.

Використання препарату помірно активізує процеси метаболізму в організмі козенят: підвищує вміст загального білку

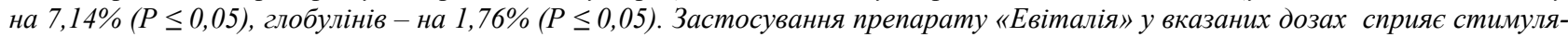
иії природної резистентності організму козенят: гуморальні показники захисту (БАСК) зросли на 1,52\%, (ЛАСК) на 1,81\%, клітинні показники (ФА) в порівнянні з контролем були вище на -4,97\%.

Ключові слова: пробіотик «Евіталія», козенята, заанівська порода, природна резистентність, морфологічні показники крові, еритроцичти, лейкоцити загальний білок, альбуміни, глобуліни, фагоц̧итарна активність нейтрофілів, бактерицидна та лізочимна активність сироватки крові.
\end{abstract}

\section{Неспецефическая резистентность козлят за действия пробиотика «Эвиталия» в условиях не регулируемого микроклимата}

\author{
А.Н. Петренко, Л.Л. Кущ \\ Petrenko@e-mail.ua
}

\author{
Харьковская государственная зооветеринарная академия, \\ пгт. Малая Даниловка, Дергачевский район, Харьковская область, 62341, Украина
}

\begin{abstract}
Цель исследования заключалась в выяснение влияния пробиотической закваски «Евиталия» на неспечифическую резистентность козлят зааневской породы в условиях микроклимата согласно ВНТП (для овцеводческих и козоводческих предприятий): температура воздуха в помещении $12-14{ }^{\circ} \mathrm{C}$, относительная влажность $55-70 \%$, вміст діоксиду вуглеию - 1,5

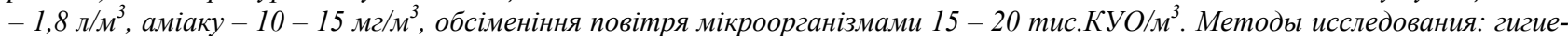
нические, гематологические, биохимические, иммунологические, статистические. Получение результаты и их новизна: впервые испьтана новая пробиотическая закваска «Эвиталия», при пероральном введении ее козлятам в дозе 200 мл/голову - утром и вечеромпо 100 мл Установлено, что применение «Эвиталия» способствует активизаиии окислительновосстановительных процессов в организме козлят, стимуляции эритропоэза: повышение концентрации гемоглобина на $0,56 \%(P \leq 0,05)$, количество эритрочитов - 10,2\% $(P \leq 0,05)$.

Применение препарата умеренно активизирует процессы метаболизма в организме козлят: повышает содержание

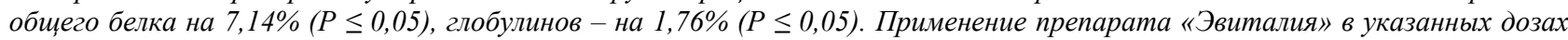
способствует стимуляции естественной резистентности олрганізму козлят: гуморальные показатели защчтты (БАСК) увеличились на 1,52\%, (ЛАСК) на 1,81\%, клеточные показатели (ФА) в сравнении с контролем были выме на - 4,97\%.
\end{abstract}

Citation:

Petrenko, A.N., Kushch, L.L. (2016). Nespetsifichna kids resistance under probiotics «Evitaliya» under no adjustable microclimate. Scientific Messenger LNUVMBT named after S.Z. Gzhytskyj, 18, 3(70), 196-199. 
Ключевые слова: пробиотик «Эвиталия», козлята, зааневской порода, естественная резистентность, морфологические показатели крови, эритроциты, лейкоциты, общчй белок, альбумины, глобулинь, фагочитарная активность нейтрофилов, бактерицидная и лизочимная активность сыворотки крови.

\title{
Nespetsifichna kids resistance under probiotics «Evitaliya» under no adjustable microclimate
}

\author{
A.N. Petrenko, L.L. Kushch \\ Petrenko@e-mail.ua \\ Kharkiv state academy veterinarian, \\ village Small Danilovka, Dergachi district, Kharkiv region, 62341, Ukraine
}

\begin{abstract}
Probiotic «Evitaliya» is freeze-dried, specific strains of lactic acid microorganisms (Lactococcus lactis, Streptococcus thermophilus, Lactobacillus acidophilus, Lactobacillus helveticus, Propionibacterium fredenreichii ssp shernanii), they contain vitamins B1, B2, B6, B12, A, E, C iron minerals, calcium, magnesium.

The purpose of the study was to clarify the effect of the probiotic ferment «Evitaliya» on nonspecific resistance of kids zaanovskoy breed microclimate conditions according VNTP (for sheep and goat breeding enterprises): the room temperature 12$14{ }^{\circ} \mathrm{C}$, relative humidity of $55-70 \%$, the carbon dioxide content $-1.5-1.8 \mathrm{l} / \mathrm{m}^{3}$ and ammonia $-10-15 \mathrm{mg} / \mathrm{m}^{3}$ air bacterial contamination $15-20$ tys. KOE $/ \mathrm{m}^{3}$. Implementation of this goal was decided to use hygienic (temperature, relative humidity, air velocity); hematological (red blood cells, white blood cells, hemoglobin), biochemical (total protein, albumin, globulin); immune (humoral factors - lysozyme and bactericidal activity of blood serum, cell - the neutrophil phagocytic activity), statistics

Getting results and their novelty: for the first time tested the new probiotic yeast «Evitaliya», with its goats orally at a dose of $200 \mathrm{ml} / \mathrm{head}$ in the morning and evening, $100 \mathrm{ml}$.

It was found that the use of «Evitaliya» promotes activation of redox processes in the body kids, stimulation of erythropoiesis: increase in hemoglobin concentration of $0.56 \%(P \leq 0.05)$, the number of red blood cells to $-10.2 \%(P \leq 0.05)$.

Use of the drug is moderately activates metabolic processes in the body of kids: increases total protein content by $7.14 \%(P \leq$ $0.05)$, globulin - by $1.76 \%(P \leq 0.05)$. Use of the drug «Evitaliya» at the indicated doses helps stimulate natural resistance olrganizmu kids: humoral protection indicators (BASK) rose by $1.52 \%$ (LASK) by $1.81 \%$, the cell indices (FA) compared to the control were higher $-4.97 \%$

Key words: probiotic «Evitaliya» goats, zaanovskoy breed, natural resistance, morphological parameters of blood, red blood cells, white blood cells, total protein, albumin, globulin, phagocytic activity of neutrophils, bactericidal and lysozyme activity of blood serum.
\end{abstract}

\section{Ветуп}

В сучасних умовах перевага наддається таким (БАР), які не здатні накопичуватись в організмі, не забруднюють оточуюче середовище при виведенні нього, а самі метаболізуються, здійснюючи позитивний вплив на формування біологічної продукції.

Науковцями встановлені різноманітні зв'язки продуктивності сільськогосподарських тварин з енергетичними процесами в органах і тканинах. Обмін речовин та енергії $\epsilon$ найбільш суттєвим ланцюгом в життєдіяльності організму, особливо при дії на нього кормових факторів, мікроклімату приміщень, зовнішнього середовища та технологічних прийомів ведення галузі (Trubnikov, 2007). Для зменшення негативного впливу цих факторів на організм тварин у ветеринарній медицині на сучасному етапі значна увага приділяється пошукам і застосуванню натуральних біологічно активних речовин, які стимулюють ріст і розвиток тварин, підвищують резистентність організму, їх стійкість до захворювань та збереженість поголів'я, зменшують витрати корму на одиницю продукції.

На сучасному етапі ведення тваринництва вчені значну увагу приділяють контролю над рівнем природної резистентності організму. Відомо, що рівень резистентності організму змінюється залежно від багатьох факторів, зокрема від віку тварин, пори року, годівлі, умов утримання, впливу на організм хімічних, фізичних, біологічних та інших чинників (Bokun et al.,
2002; Derevjanko et al., 2004). Питанням резистентності, або імунітету в сучасній біології донедавна не приділяли належної уваги в наукових дослідженнях, а, особливо, в практичній діяльності спеціалістів тваринницької галузі (Kosenko et al., 2004; Panin et al., 2012; Trubnikov, 2007; Chornyj et al., 2016).

Головною особливістю закваски «Евіталія» є здатність мікроорганізмів збражувати вуглеводи без утворення газів, але з утворенням кислот, які закислюють вміст кишечнику і тим самим пригнічують ріст гнилісних та умовно-патогенних мікробів, знижують навантаження на печінку за рахунок зменшення утворення амінів, енерготоксинів та інших речовин мікробного походження, що мають благотворну дію на підвищення загальної резистентності.

\section{Матеріал і методи досліджень}

Для дослідження були відібрані козенята заанівської породи. Тварини, за принципом аналогів, були розподілені на контрольну та дослідну групи, по 10 голів у кожній: контрольна група одержувала повнораціонне годування, дослідній - крім загального раціону задавали перорально двічі на добу в дозі 200 мл/голову вранці та ввечері - по 100 мл закваски «Евіталія» за прийом.

Закваска «Евіталія» представляе собою ліофільно висушені, але здатні розмножуватися в травному тракті, спеціальні штами молочнокислих та інших мік- 
роорганізмів (Lactococcus lactis, Streptococcus thermophilus, Lactobacillus acidophilus, Lactobacillus helveticus, Propionibacterium fredenreichii ssp. shernanii) та вітаміни: $\mathrm{B}_{1}, \mathrm{~B}_{2}, \mathrm{~B}_{6}, \mathrm{~B}_{12}, \mathrm{~A}, \mathrm{E}, \mathrm{C}$, фолієву кислоту, мікроелементи заліза, кальцію, магнію та ін.

Рівень резистентності організму козенят оцінювали за морфологічним складом та вмістом загального білку і білкових фракцій в сироватці крові. Кров для досліджень у козенят брали до годування $з$ яремної вени. У крові визначали: концентрацію гемоглобіна по Салі; кількість лейкоцитів і еритроцитів - в камері 3 сіткою Горяєва; загальний білок сироватки крові і його фракції - рефрактометричним методом; показники неспецифічної резистентності: фагоцитарну активність (ФА) по В.Е. Чумаченко, бактерицидну активність сироватки крові (БАСК ) по О.В. Смирнової та Кузміною, лізоцимну активність сироватки крові (ЛАСК) по Маркову Ю.М. та ін. Піддослідні тварини, які одержували препарат «Евіталія», мали гарний апетит, були рухливі.

\section{Результати та їх обговорення}

Мікроклімат, де утримувались піддослідні козенята характеризувався наступними показниками: температура повітря була в межах $12-14{ }^{\circ} \mathrm{C}$, відносна вологість $55-70 \%$, вміст діоксиду вуглецю $-1,5-1,8 л / \mathrm{m}^{3}$, аміаку $-10-15 \mathrm{M} / \mathrm{M}^{3}$, обсіменіння повітря мікроорганізмами 15 - 20 тис.КУО/м³. В цілому параметри мікроклімату відповідали нормативам ВНТП АПК 03.05 для вівчарських та козівничих підприємств.

Гематологічні показники об'єктивно відображують клінічний статус та стан здоров'я козенят( таблиці 1)

Таблиия 1

Морфологічний склад крові козенят $(\mathrm{M} \pm \mathbf{m}, \mathbf{n}=\mathbf{5})$

\begin{tabular}{|c|c|c|c|}
\hline Групи тварин & Еритроцити Т/л & Лейкоцити Г/л & Гемоглобін г/л \\
\hline \multicolumn{1}{|c|}{ На початку досліду } & $10,20 \pm 0,22$ & $116,30 \pm 0,68$ \\
\hline Контрольна & $10,20 \pm 0,13$ & $10,30 \pm 0,16$ & $116,30 \pm 0,53$ \\
\hline Дослідна & $10,20 \pm 0,19$ & $12,00 \pm 0,16$ & $116,06 \pm 0,29$ \\
\hline \multicolumn{4}{|c|}{ У кінці досліду } \\
\hline Контрольна & $10,62 \pm 0,12$ & $11,13 \pm 0,21^{* *}$ & $116,95 \pm 0,26^{*}$ \\
\hline Дослідна & $11,70 \pm 0,27^{* *}$ &
\end{tabular}

Примітка $* P \leq 0,05 * * P \leq 0,01, * * * P \leq 0,001$

Слід відмітити, що найкращі показники спостерігалися в дослідній групі при згодовуванні «Евіталія». Так кількість еритроцитів в цій групі була більша ніж в контрольній групі на 10,2\%, відповідно. В той же час кількість лейкоцитів в цій групі була на 6,9\% менше, ніж в контрольній. Таким чином, наведені в табл. 1 дані свідчать про те, що в стресовий період морфологічні показники крові погіршуються, а використання закваска «Евіталія» покращує ії морфологічний склад, збільшує кількість еритроцитів та концентрацію гемоглобіну, що забезпечує кращу оксигенацію та біосинтетичні процеси в тканинах організму.

Одним з показників природної резистентності організму є білковий спектр сироватки крові(табл. 2).

Табличя 2

Вміст загального білку та білкових фракцій в сироватці крові $(\mathbf{M} \pm \mathbf{m}, \mathbf{n}=\mathbf{5})$

\begin{tabular}{|c|c|c|c|c|c|}
\hline \multirow{2}{*}{ Групи } & \multirow{2}{*}{$\begin{array}{c}\text { Загальний } \\
\text { білок, г/л }\end{array}$} & \multirow{2}{*}{ Альбуміни, \% } & \multicolumn{3}{|c|}{ Глобуліни, \% } \\
\hline & & & $\alpha$ & $\beta$ & $\gamma$ \\
\hline \multicolumn{6}{|c|}{ На початку досліду } \\
\hline Контрольна & $67,02 \pm 0,09$ & $48,82 \pm 0,15$ & $13,20 \pm 0,19$ & $12,00 \pm 0,16$ & $26,00 \pm 0,11$ \\
\hline Дослідна & $63,02 \pm 0,11$ & $48,56 \pm 0,14$ & $12,40 \pm 0,20$ & $13,56 \pm 0,14$ & $25,50 \pm 0,17$ \\
\hline \multicolumn{6}{|c|}{ У кінці досліду } \\
\hline Контрольна & $67,02 \pm 0,09$ & $48,82 \pm 0,15$ & $13,20 \pm 0,19$ & $12,00 \pm 0,16$ & $26,00 \pm 0,11$ \\
\hline Дослідна & $67,52 \pm 0,17$ & $49,48 \pm 0,10^{*}$ & $14,90 \pm 0,16^{* *}$ & $8,75 \pm 0,12 * * *$ & $26,90 \pm 0,13 * *$ \\
\hline
\end{tabular}

Примітка $* P \leq 0,05 * * P \leq 0,01, * * * P \leq 0,001$

Як свідчать дані табл. 2 на початку досліду показники загального білку і його фракцій в сироватці крові у всіх групах були приблизно однакові. Спостерігається помітне зростання вмісту білкових фракцій, альбумінів та гамма-глобулінів, які характеризують гуморальний захист організму. Так при згодовуванні «Евіталія», кількість альбумінів перевищує контроль на 1,4\%, а гамма-глобулінів - відповідно 3,5\%. Але всі показники білкових фракцій сироватки крові ягнят та співвідношення між альбуміновими і глобуліновими фракціями знаходяться в межах допустимих норм.
Таким чином, зростання питомої ваги гаммаглобулінів (імуноглобулінів) в глобуліновій фракції, які забезпечують гуморальний захист організму, при використанні препарату «Евіталія» свідчить, про підвищення природної резистентності тварин, характеризує морфологічну зрілість і функціональну повноцінність імунореактивної системи.

Стан неспецифічної резистентності організму забезпечується клітинними та гуморальними показниками крові (табл. 3 ). 
Показники неспецифічної резистентності козенят при згодовуванні закваски «Евіталія». $(\mathbf{M} \pm \mathbf{m}, \mathbf{n}=5)$

\begin{tabular}{|c|c|c|c|}
\hline Групи тварин & ФА, $\%$ & ЛАСК, \% \\
\hline \multicolumn{4}{|c|}{ На початку досліду } \\
\hline Контрольна & $32,52 \pm 0,14$ & $76,32 \pm 0,20$ & $29,82 \pm 0,12$ \\
\hline Дослідна & $32,50 \pm 0,16$ & $76,38 \pm 0,12$ & $29,86 \pm 0,17$ \\
\hline \multicolumn{2}{|c|}{ У кінці досліду } \\
\hline Контрольна & $31,38 \pm 0,07$ & $76,90 \pm 0,11$ & $28,76 \pm 0,10$ \\
\hline Дослідна & $32,94 \pm 0,09^{* * *}$ & $77,54 \pm 0,12^{*}$ & $30,40 \pm 0,10^{* * *}$ \\
\hline
\end{tabular}

Примітка *P $\leq 0,05 * * P \leq 0,01, * * * P \leq 0,001$

Дані таблиці 3 свідчать про те, що показники, які характеризують природну резистентність організму, знижують фагоцитарної активності на $-4,97 \%$, лізоцимної - на 5,70\%, бактерицидна активністі сироватки крові навпаки підвищується на $0,83 \%$ порівняно 3 контрольною групою (P $<0,05)$. Дослідження свідчать про позитивний вплив препарату «Евіталія» на підвищення природної резистентності організму та зменшення впливу стресового фактору на козенят.

\section{Висновки}

Використання препарату «Евіталія» має стимулюючий вплив на показники неспецифічної природної резистентності організму козенят, підвищує БАСК і ЛАСК та знижує дію стрес-факторів.

\section{Бібліографічні посилання}

Bokun, A.A. Derevjanko, S.V., Djachenko, G.M. (2002). Primenenie probiotikov V zhivotnovodstve. Veterinarnaja medicina. 80, 94-97 (in Ukrainian).

Derevjanko, S.V., Djachenko, T.M., Bozhok, L.V. (2004). Probiotychni preparaty dlja profilaktyky i likuvannja hvorob ta stymuljacii' rostu sil's'ko-gospodars'kyh tvaryn i ptyci. Veterynarna medycyna. 84, 819-823 (in Ukrainian).

Kosenko, M.V., Malyk, O.G.,. Kosenko, Ju.M. (2004). Problemy ekologii'. L'viv: Dobra sprava. 273-368 (in Ukrainian).

Panin, A.N., Malik, N.I., Ilaev, O.S. (2012). Probiotiki v zhivotnovodstve - sostojanie i perspektivy. Veterinarija. 3, 3-8 (in Ukrainian).

Trubnikov, P.V. (2007). Korreljacija immunologicheskih i gematologicheskih pokazatelej krovi koz. «Sostojanie, perspektivy, strategija razvitija i nauchnogo obespechenija ovcevodstva i kozovodstva RF»: mezhd. nauch.-prakt. konf. Stavropol'. GNU SNIIZhK. 3, 34-37 (in Russian).

Chornyj, M.V., Petrenko, A.M., Kushh, L.L., Logachova L.O. (2016). Vykorystannja Mobes i vitaminu V12 pry vyroshhuvanni kozenjat v umovah neregul'ovanogo mikroklimatu. Nauk. visnyk L'vivs'kogo nacional'nogo universytetu veterynarnoi' medycyny ta biotehnologii' im. S.Z. Gzhyc'kogo. L'viv. 18, 1(65), 2, 196-202 (in Ukrainian).

Стаття надійшла до редакиії 1.10.2016 